\title{
REVIEW ARTICLE State of the science and challenges of breeding landscape plants with ecological function
}

\author{
H Dayton Wilde ${ }^{1}$, Kamal JK Gandhi ${ }^{2}$ and Gregory Colson ${ }^{3}$
}

Exotic plants dominate esthetically-managed landscapes, which cover 30-40 million hectares in the United States alone. Recent ecological studies have found that landscaping with exotic plant species can reduce biodiversity on multiple trophic levels. To support biodiversity in urbanized areas, the increased use of native landscaping plants has been advocated by conservation groups and US federal and state agencies. A major challenge to scaling up the use of native species in landscaping is providing ornamental plants that are both ecologically functional and economically viable. Depending on ecological and economic constraints, accelerated breeding approaches could be applied to ornamental trait development in native plants. This review examines the impact of landscaping choices on biodiversity, the current status of breeding and selection of native ornamental plants, and the interdisciplinary research needed to scale up landscaping plants that can support native biodiversity.

Horticulture Research (2015) 2, 14069; doi:10.1038/hortres.2014.69; Published online: 28 January 2015

\section{INTRODUCTION}

Recent ecological studies have found that landscaping choices can affect biodiversity in urbanized areas. ${ }^{1-5}$ The impact of land use practices in esthetically-managed landscapes of the United States was summarized in a US Environmental Protection Agency report, ${ }^{6}$ which noted:

- the widespread replacement of millions of acres of native vegetation with primarily non-native ornamental plants in managed landscapes is a growing problem for the organisms that depend on native plants for food, shelter, and places to rear their young;

- many studies have documented the negative effect that nonnative plants can have on the abundance and diversity of insect herbivores;

- if ornamental plants cannot serve as food for the same number and diversity of herbivores, the energy available for food webs decreases.

Non-native or exotic plants can be defined as plant species that evolved someplace other than where they have been introduced. Native plants, in contrast, share an evolutionary history with regional insects and other organisms. The observations of Erlich and Raven, ${ }^{7}$ with further modification, ${ }^{8}$ have led to an understanding of plant and insect co-evolution in which the adaptation of insects to plant defenses plays an important role. Landscaping primarily with exotic plant species would be expected to be detrimental to insect herbivores that have adapted to native plant hosts ${ }^{9}$ and recent studies support this hypothesis. ${ }^{1,2,10,11}$ Changes caused by exotic plants to the abundance and diversity of insects, and the birds that consume them, are discussed in the following section. The impact of exotic landscaping plants on other native taxa is less well studied. The spread of invasive exotic plants, however, has been linked to a decline in the diversity of reptiles, spiders and mycorrhizal fungi. ${ }^{12-15}$ Invasive exotic plants can affect native species through food-web dynamics or by less predictable mechanisms. ${ }^{16}$
To conserve biodiversity in urbanized areas, the increased use of native plant species in designed landscapes has been advocated by conservation groups and US federal and state agencies. This includes NGOs such as the National Wildlife Federation, the Audubon Society and the Native Conservancy and government agencies such as the EPA, the USDA and the DOT. The implementation of this goal on an effective scale faces several hurdles. There are over 32 million hectares of esthetically managed land in the United States, including urban and suburban landscapes ${ }^{17}$ and highway corridors. ${ }^{18}$ The developed area of the United States is projected to increase by nearly $80 \%$ in the first quarter of this century, ${ }^{19}$ adding millions more hectares of landscaping. The amount of land managed for esthetics is similar in scale to the land in corn cultivation $(37 \mathrm{M} \text { ha in } 2014)^{20}$ or in all US national and state parks (40M ha). ${ }^{21}$ Increasing native plant landscaping to $30 \%$, for example, of the managed landscape would require a significant expansion of what is now a niche market.

A major challenge to scaling up the use of native species in landscaping is in providing ornamental plants that are both ecologically functional and economically viable. Similar to environmental restoration with native plants, attention should be paid to genetic diversity and local adaptability. ${ }^{22}$ Unlike environmental restoration, though, native plants must be introduced into managed landscapes through a market system in which landscaping plants that meet consumer demand are delivered profitably by the horticulture industry. Ecological function, cost-effective production and ornamental traits are qualities desired in native landscaping material that are potentially conflicting. The scale-up of landscaping plants that can support biodiversity would benefit from interdisciplinary research in genetics, ecology, and economics.

\section{EFFECTS OF EXOTIC PLANTS ON INSECT AND BIRD ABUNDANCE AND DIVERSITY}

The prevalence of exotic plants in a landscape may alter the number of ecologically important insects, as well as the composition of

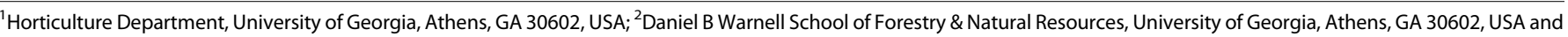
${ }^{3}$ Department of Agricultural and Applied Economics, University of Georgia, Athens, GA 30602, USA

Correspondence: HD Wilde (dwilde@uga.edu)

Received: 17 November 2014; Revised: 19 December 2014; Accepted: 20 December 2014
} 
insect populations. In the northeastern United States, a comparison of suburban yards landscaped with native or exotic plants found that exotic plants reduced the abundance and diversity of lepidopteran insects. ${ }^{1}$ A study of urban vegetation in Singapore determined that lepidopteran diversity correlated directly with the percentage of native plants. ${ }^{2}$ Field trials confirmed the negative impact of exotic plants on specialist and generalist lepidopteran numbers ${ }^{10}$ and found a similar effect on insects of other taxa and feeding guilds. ${ }^{11,23,24} \mathrm{~A}$ study in which old-field plant communities were manipulated found that insect species richness was reduced on exotic plants, although insect abundance was similar on native and exotic plants. ${ }^{25}$ While the effects of exotic plants on insects may differ between studies, the geographic origin of introduced plants was found to change insect community structure.

Invasive exotic plants can also alter insect populations. ${ }^{26-28}$ This is relevant to ornamental plants since many exotic species that have become invasive in the United States were introduced for landscaping purposes. ${ }^{29}$ Field studies have found that invasive exotic plants can shift the insect population from large, specialist insects (e.g., lepidoptera) to small, generalist insects (e.g. dipteran midges), significantly reducing insect biomass. ${ }^{26}$ Some invasive exotic plants, such as honeysuckle (Lonicera maackii), may increase insect species richness and numbers by creating a more complex vegetative structure. ${ }^{30}$ Separately, honeysuckle was found to cause a decrease in caterpillar abundance that was moderated when there was higher tree diversity and more intact forest cover. ${ }^{31}$ Habitat fragmentation and homogeneity are common features of urban landscapes and they may mediate the effects of exotic plants on insect herbivores.

Studies have indicated that several life-history attributes of insects may be altered due to exotic plants. Insect size, egg load and attraction to mates were reduced, and developmental period was longer on exotic species. ${ }^{32,33}$ Native pollinators may visit abundant exotic plants more frequently, thus lowering pollination of native plants. ${ }^{34}$ Lower feeding damage on exotic than on native plants has been reported, perhaps due to lower nutrient quality. ${ }^{35,36}$ An exotic plant with foliage that is toxic to caterpillars can be a dead-end host for a native butterfly species. ${ }^{37}$ This may allow exotic plant species to escape herbivory, and persist and spread on the landscape. Overall, while exotic plants can provide certain ecological services, ${ }^{25,30,38}$ their ability to support native insects is limited in many ways.

Changes in insect quality and quantity can affect higher trophic levels through food web interactions. As argued by Tallamy, ${ }^{9}$ nearly all terrestrial birds in North America rear their young on insects, with food being a major limitation to breeding success. ${ }^{39,40}$ Two studies on the ecological impacts of plant origin, discussed previously with regard to insects, also examined effects on bird populations. ${ }^{1,2}$ In suburban Pennsylvania yards landscaped with exotic plants, a reduction in bird abundance and diversity correlated with the decrease in lepidopteran populations. ${ }^{1}$ Both avian and lepidopteran species richness varied directly with the percentage of native shrubs and trees in urban vegetation of Singapore. ${ }^{2}$ The presence of native landscaping plants was found to have a positive effect on native bird abundance and diversity in urbanized areas across different environments. ${ }^{3-5,41}$ Lepidoptera and birds have served as surrogate taxa in biodiversity studies because they are environmentally sensitive and relatively easy to measure. ${ }^{1,42}$ The corresponding changes in native lepidopteran and avian populations could be causative (fewer caterpillars make birds forage elsewhere) or correlative (exotic plants negatively affect butterflies and birds independently).

\section{CURRENT STATUS OF THE BREEDING AND SELECTION OF NATIVE ORNAMENTAL PLANTS}

A niche market has developed in the United States for native ornamental plants that provide wildlife support, as well as local adaptability. The single largest venture directed at this market is the
American Beauties ${ }^{\mathrm{TM}}$ program, a partnership between the National Wildlife Federation and two wholesale nurseries. ${ }^{43}$ The program distributes native landscaping plants to independent garden centers and landscapers in the northeastern United States. Over 350 plant species are provided through this system, including native perennials, grasses, vines, trees and shrubs. In addition, Armitage $^{44}$ describes more than 400 native ornamental plants, primarily herbaceous species, that can be ordered directly from local nurseries in the United States.

Native plants for ornamental horticulture generally come from breeding, genotype selection or open-pollinated seed. Within the American Beauties $^{\mathrm{TM}}$ inventory, approximately $35 \%$ of the plants are named cultivars and $65 \%$ are propagated genotypes of native species. North American plant species have been selected or bred for flowering, architecture, foliage and disease-resistance traits, although not to extent of exotic ornamentals. For example, native plant genotypes have been selected that exhibit early flowering (e.g., Potentilla fruticosa 'KM01') ${ }^{45}$ or double flowers (e.g., Cercis canadensis 'Flame'). ${ }^{46}$ From an open-pollination breeding program, an oak leaf hydrangea genotype (Hydrangea quercifolia 'Snow Queen') was identified that had low, compact form and abundant, showy blooms. ${ }^{47}$ Controlled pollination was used to develop a beebalm genotype (Monarda didyma 'Sugar Lace') with a modified branching pattern and powdery mildew resistance. ${ }^{48}$ Through the interspecific hybridization of Baptisia australis and B. bracteata, a false indigo genotype (Baptisia $\times$ bicolor 'Starlite') was produced that had early and abundant flowering. ${ }^{49}$

Most breeding and selection of North American plant species for ornamental traits has been conducted by private sector programs, including some in Europe. ${ }^{45,48}$ Native perennial plants for mid-western US landscapes have been bred at the Chicago Botanic Garden using wild collected germplasm and cultivated plants from nursery sources. ${ }^{50}$ Genera targeted in this program include Asclepias (milkweed), Baptisia (false indigo), Echinacea (purple coneflower), Liatris (blazing star) and Penstemon (beardtongue). Public breeding programs at US universities have developed horticultural traits in native plants of genera such as Aronia (chokeberry) ${ }_{1}^{51}$ Cercis (redbud) ${ }_{1}^{52}$ Cornus (dogwood), ${ }^{53}$ Penstemon ${ }^{54}$ and Vaccinium (blueberry). ${ }^{55}$

\section{ECOLOGICAL SERVICES AND ADAPTABILITY OF NATIVE ORNAMENTAL PLANTS}

Many native landscaping plants available in the horticultural trade are vegetatively-propagated genotypes that have been selected or bred for ornamental characteristics. There is little information about whether native ornamental cultivars can provide the same ecological services as their parent species. One study compared two cultivars of ninebark (Physocarpus opulifolius) and a local genotype (Minnesota, USA) as hosts for the ninebark beetle (Calligrapha spiraeae), a specialist herbivore. ${ }^{56}$ Controlled-feeding experiments found significant differences in feeding preference between the local ninebark and the purple-leaved cultivar 'Monlo', but not between the local ninebark and the yellow-leaved cultivar 'Dart's Gold'. Leaves of 'Dart's Gold' and the local ninebark had at least fourfold less anthocyanins, a potential feeding deterrent, than the purple leaves of 'Monlo'. These results indicate that while native cultivars can support specialist insects, this may vary with the ornamental trait.

Field studies comparing the effect of native plant cultivars and ecotypes on insect populations are being conducted at two botanical gardens in the United States, the Mt Cuba Center (Delaware) ${ }^{57}$ and the State Botanical Garden of Georgia (James Affolter, pers. comm.). At the US National Arboretum, a field study is in progress that compares the impact of native and exotic ornamentals on predatory insects (e.g., parasitic hymenoptera). ${ }^{58}$ The range over which a native cultivar can provide an ecological service, such as food-web support, has not been investigated. Scaling up the use of 
native plants will likely require that they be marketed on a regional basis. The genetic diversity needed in native ornamentals to provide ecological services across a regional market needs to be examined. There are similar concerns regarding the diversity needed for native plant adaptability in ecological restoration projects. ${ }^{22}$

For ecological restoration, environmentally defined regions can be used to estimate where native plant material is suitable. ${ }^{59-61}$ EPA ecoregions, for example, are geographic areas with similar geology, climate, vegetation, soils and hydrology. Ecoregions I through IV are hierarchical classifications of land areas, with environmental similarity increasing at each level. Level III ecoregions have been used to estimate seed transfer zones, ${ }^{62,63}$ i.e., a region within which plant material can be distributed with little risk of maladaptation. ${ }^{60}$ Figure 1 shows, for example, a level III ecoregion that encompasses the Appalachian piedmont of the United States. Miller and colleagues ${ }^{62}$ found that a level III ecoregion could serve as a seed transfer zone for four of the five native plant species that they examined. Climatic data alone ${ }^{60}$ or in combination with ecological data ${ }^{61}$ have also been used to predict regions suitable for native plant material.

For ornamentals, the regional limits of cultivar adaptability are already considered by many consumers and retailers through USDA hardiness zone ratings. Like native plant genotypes for restoration, native cultivars for landscaping could potentially be adaptable throughout a level III ecoregion or other environmentally-defined region. Research is needed on food-web support by native cultivars on a regional basis. Level III ecoregions may also be of sufficient size to be markets for native landscaping plants. The Appalachian piedmont ecoregion, for example, contains several expanding metropolitan areas in the southeast United States, including Atlanta, Charlotte and Raleigh-Durham (Figure 1).

\section{SCALING UP THE USE OF NATIVE ORNAMENTALS}

Native plants make up approximately $13 \%$ of the total sales of the nursery industry in the United States. ${ }^{64}$ To understand the issues limiting the use of native plants in landscaping, surveys have been conducted of nursery retailers, ${ }^{43,65}$ landscape architects ${ }^{66,67}$ and Master Gardeners. ${ }^{68}$ Three general factors that were consistently considered important in survey responses were (i) the availability of native plants; (ii) consumer preferences; and (iii) knowledge about native plants. With regard to native plant education, botanical gardens and citizen science can be effective vehicles for increasing public awareness of the cultivation and ecological value of native plants. $^{69-71}$

Increasing the availability of native ornamentals would be accomplished most efficiently through existing supply chains. The major routes to market for ornamental plants in the United States, based on sales from nurseries, were through landscape firms (31\%), garden centers $(22 \%)$, re-wholesalers $(21 \%)$ and mass merchandisers (9\%). ${ }^{64,72}$ The plants distributed through these channels are primarily cultivars of exotic species. Scaling up native ornamentals through established distribution procedures would most likely require propagated selections of a limited number of genotypes. An economic assessment is needed of the number of different genotypes of native ornamental species that can be delivered profitably by the horticulture industry for a regional market. An alternative or complement to mainstream supply chains would be the distribution of local ecotypes by smaller nurseries specializing in native plants. It is likely that both specialty and mainstream outlets will be needed to scale up the availability of native ornamentals to consumers.

Native landscaping plants need to meet consumer preferences regarding ornamental qualities and compete with exotic alternatives in the marketplace. Native plants can often be more expensive than exotic plants, perhaps as a result of their small scale of production. ${ }^{73}$ The cost of native ornamentals, however, was identified in surveys as one of the least important factors limiting their adoption. ${ }^{43,65-68}$ Interestingly, consumers were found to be willing to pay more for well-designed yards that included native plants instead of lawns. ${ }^{74}$ This was determined by a contingent choice survey in which consumers in Michigan were presented with hypothetical options that varied in purchase and maintenance costs. ${ }^{74}$ Complementing this approach, non-hypothetical auctions were conducted in Minnesota where consumers bid on native and exotic ornamental plants. ${ }^{75,76}$ In experimental auctions, consumers were willing to pay a $\$ 0.35$ premium for plants labeled as non-invasive and native. ${ }^{75}$ Purchasing patterns indicated that approximately $50 \%$ of consumers considered that plants labeled as 'native' or 'non-invasive' were worth a cost premium. ${ }^{76}$ Environmental qualities of native ornamentals could therefore be considered valueadded traits that may be signaled to consumers via information and labeling strategies.

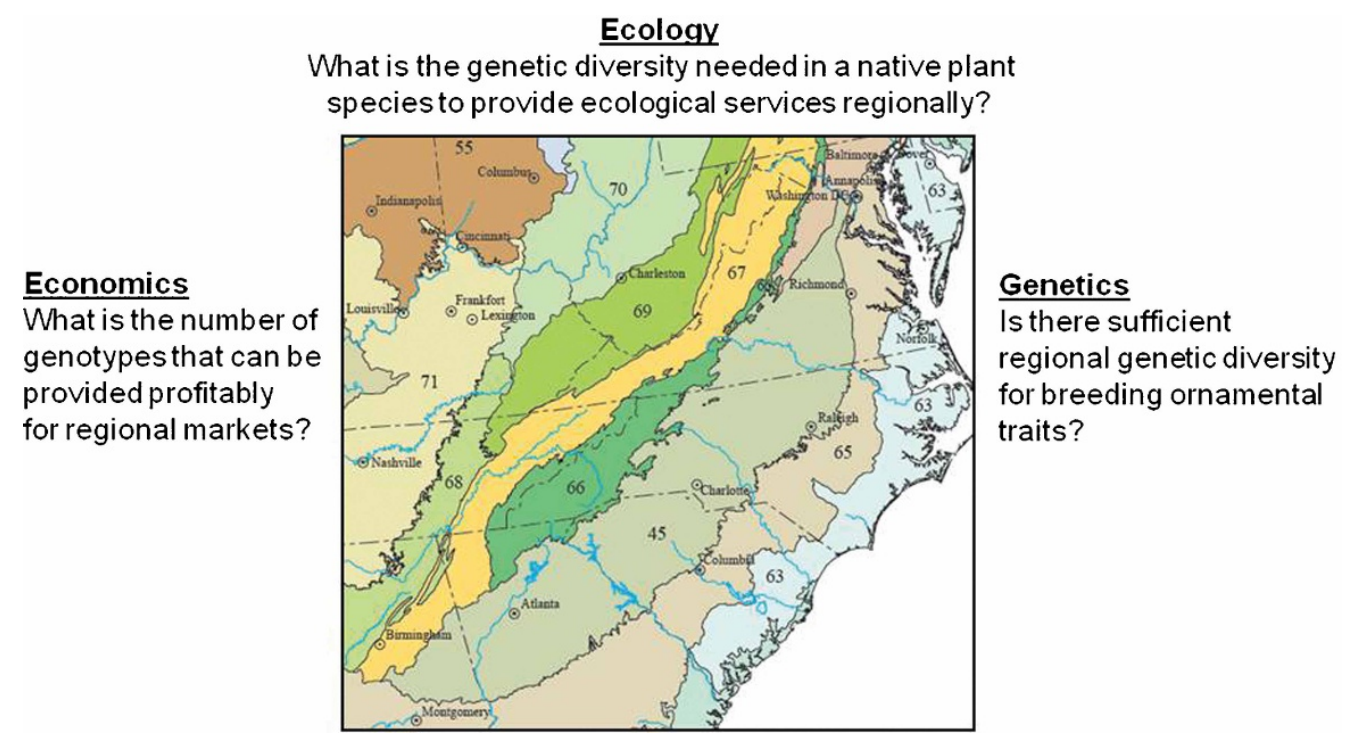

Figure 1. EPA level III ecoregions in the eastern United States. Different shades and numbers indicate different ecoregions, with \#45 designating the Appalachian Piedmont. Ecoregions could be useful for studying interrelated questions of genetics, ecology, and economics posed by scaling up native plants. 
Half of consumers in the same study purchased ornamentals based on plant traits, not plant origin or invasive potential. ${ }^{76}$ Traits of ornamental plants that are popular with consumers include extended flowering, novel floral morphology (e.g., double flowers), compactness, and disease-resistance. 'Knockout' roses, 'Encore' azaleas and 'Endless Summer' hydrangeas are examples of top-selling exotic cultivars in the United States that have one or more of these characteristics. Some of the native ornamental species that are currently available have been selected for traits such as double flowers, ${ }^{46}$ reduced stature ${ }^{47}$ and foliage color. ${ }^{56}$ Further development of native ornamentals with flowering, architecture or drought-tolerance ${ }^{77}$ traits may be a strategy to increase native plant use among a large segment of the consumer market.

\section{ACCELERATED BREEDING OF ORNAMENTAL TRAITS IN NATIVE PLANTS}

Molecular breeding could be used to accelerate the development of native plants species with ornamental traits. Molecular markers have been used with ornamental plants primarily to identify cultivars, conduct pedigree analysis and study germplasm variability. ${ }^{78}$ Markers have also been developed in a few cases for breeding traits such as disease resistance in roses ${ }^{79}$ and flowering time in chrysanthemum. ${ }^{80}$ For native ornamental plants, marker-assisted selection has the potential to accelerate cultivar development, particularly for woody species. Woody plants are an important target because (i) they have the highest wholesale value in the US ornamental plant market; ${ }^{81}$ and (ii) the hosts for the greatest diversity of lepidopteran species are native woody species. ${ }^{82}$

Molecular markers have been generated for a limited number of ornamental species that are native to North America. This may be due in part to the current cost of marker development relative to the market size of a native species. Amplified fragment length polymorphism (AFLP) and simple sequence repeat (SSR) markers were developed to identify cultivars and lines of flowering dogwood (Cornus florida). ${ }^{83,84}$ The genetic diversity and population structure of $C$. florida were assessed using SSR markers. ${ }^{85}$ A genetic linkage map of $C$. florida was constructed ${ }^{86}$ and potential quantitative trait loci for red foliage were identified. ${ }^{87}$ SSR markers were examined in redbud (Cercis canadensis) in order to determine pedigree and the applicability of molecular markers to breeding. ${ }^{8,89}$ AFLP analysis was used to determine the genetic diversity and degree of introgression among several deciduous azalea species (Rhododendron sp.). ${ }^{90}$ In another woody ornamental, chokecherry (Prunus virgini$a n a)$, a major quantitative trait loci for disease resistance was identified using AFLP and SSR markers. ${ }^{91}$ Saturated linkage maps ${ }^{92}$ and a genome sequence database ${ }^{93}$ have been developed for other Prunus species and other Rosaceae members that could be used in ornamental trait development. Among herbaceous North American species, genetic diversity has been examined in Coreopsis leavenworthii with AFLP markers ${ }^{94}$ and in Helianthus annuus with both anonymous SSRs ${ }^{95}$ and gene-specific EST-SSRs. ${ }^{96}$

To take advantage of the genetic variation present in native plant populations, reverse genetic approaches could be employed that have been used for forestry ${ }^{97}$ and agricultural ${ }^{98,99}$ species. Strategies such as EcoTILLING or BRDA (breeding with rare defective alleles) use genetic screening to identify defective alleles of genes known to play major roles in the control of qualitative traits. Allelic variation has been detected in coding sequences by several screening methods, including DNA nuclease assays, high-resolution melting analysis and next-generation sequencing. ${ }^{99}$ The genetic screening of $100-800$ accessions from germplasm collections has identified defective variants of genes leading to targeted traits. Examples include improved lignin quality in black poplar (Populus nigra) ${ }^{97}$ virus resistance in pepper (Capsicum sp.) ${ }^{100}$ and improved oil quality in rapeseed (Brassica napus). ${ }^{101}$
There are several ornamental traits controlled by recessive genes that could be targeted in native plants. Many of the novel flowering and architecture phenotypes that have been obtained by traditional breeding are due to defective alleles of single genes. ${ }^{102}$ For example, floral timing has been modified in several plant species by selecting for natural TERMINAL FLOWER1 (TFL1) mutations. TFL1 represses the transition from vegetative to reproductive growth in the shoot meristem. In perennial plants such as rose (Rosa hybrida) and woodland strawberry (Fragaria vesca), TFL1 mutations cause continuous flowering. ${ }^{103}$ In annual crop plants, such as tomato and soybean, determinate varieties were developed through selection for defective alleles of TFL 1 orthologs. ${ }^{104,105}$ Floral structure has been modified by selecting for mutations of AGAMOUS $(A G)$, a transcription factor that regulates floral organ identity. A consequence of the loss of $A G$ function is the homeotic conversion of stamens to petals to produce 'double flowers'. Natural mutations of $A G$ orthologs are responsible for double flowers in varieties of ornamental cherry, morning glory and anemone. ${ }^{106-108}$

Novel architectural traits, such as reduced stature and increased branching, have been obtained from the loss of function of particular genes. Plant stature has been altered by selection for mutations in genes for gibberellic acid biosynthesis or signaling. Natural and induced mutations in GIBBERELLIN 20-OXIDASE (GA200x) of rice led to semi-dwarf varieties that played a critical role in the Green Revolution. ${ }^{109}$ Semi-dwarf phenotypes have been induced in crop species such as apple and tomato through the knockdown of GA20ox expression ${ }^{110,111}$ and in hybrid poplar through the overexpression of GA INSENSITIVE (GAI). ${ }^{112}$ Plant branching patterns can be altered by changes in the expression of BRANCHED1 (BRC1) or TEOSINTE BRANCHED1 (TB1), two closely related transcription factors that repress axillary bud growth. Reduced branching due to TB1 overexpression was critical to maize domestication; ${ }^{113}$ conversely, the knockout of $B R C 1$ expression in Arabidopsis and tomato causes increased branching. ${ }^{14,115}$ Similar to TFL1, AG and GA200x mutations in different plant species, the loss of function of $B R C 1$ resulted in the same phenotype in diverse plants. The discovery of natural mutations in candidate genes like these could lead to ornamental traits in native plant species.

Research in model species may be useful for the identification of other genes that play major roles in ornamental traits. For example, peach (Prunus persica) is a model Rosaceae species ${ }^{116}$ that could be used to study flowering genes in woody plants. Peach has complete, autogamous flowers that are produced after a relatively short juvenile period (2-3 years) and a small, sequenced, diploid genome $(227 \mathrm{Mb})$. Although gene transfer in peach is not practical, flowers can be fertilized with mutagenized pollen to generate M1 mutants; ${ }^{117,118}$ non-chimeric M1 populations would allow early screening for mutations in targeted genes by TILLING or next-generation sequencing. In addition to the known flowering genes that have been characterized in peach, ${ }^{119-125}$ floral morphology traits have been identified. ${ }^{126,127}$ Peach flowers can be large and showy or small with curved petals (non-showy), with the 'showy' flower phenotype $(s h / s h)$ segregating as a recessive, monogenic trait. Sh has been mapped to peach linkage group $1 .{ }^{128}$ Knowledge of the peach Sh sequence and function could potentially be applied through EcoTILLING to obtain novel floral morphology in native ornamental Prunus species (e.g., P. virginiana, P. serotina, P. americana).

Other strategies that could be used to develop ornamental traits in native plants include interspecific hybridization and polyploidization. ${ }^{129}$ Interspecific hybridization can occur naturally, an example being hybrid azaleas produced by the North American species Rhododendron prunifolium and $R$. arborescens. Spatial, temporal, or biological barriers, however, usually prevent interspecific hybridization. Pre- and post-fertilization barriers can be overcome by a range of methods, including pollination techniques, ovule and embryo rescue, and polyploidization. ${ }^{129}$ Controlled crosses with 
stored pollen were used to hybridize the North American natives Franklinia alatamaha and Gordonia lasianthus for woody ornamental development. ${ }^{130}$ Polyploidization has been induced in order to restore fertility in interspecific crosses, e.g., native azalea hybrids. ${ }^{131}$ Ornamental traits have also been developed directly through polyploidization, such as increased flower size in the North American species Phlox subulata. ${ }^{132}$ Genetic transformation or genome editing may be a more direct means to obtain certain traits, but such approaches are rarely economically viable for ornamental plants. ${ }^{81}$

During ornamental trait development in native plant species, the trait and the source material should be chosen to maintain ecological and adaptive functions. A purple foliage trait, for example, could reduce food-web support. For environmental restoration, local provenances are usually the best adapted material, although exceptions to the 'local is best' guideline may increase with climate change. ${ }^{133,134}$ The success of molecular markers for detecting the adaptive potential of native plant species has been mixed. For example, AFLP markers did not to reveal population differentiation related to local adaptation for three herbaceous perennial species native to Minnesota, ${ }^{135}$ whereas AFLP markers could delineate local seed collection zones for a native Australian tree species. ${ }^{137}$ Nextgeneration sequencing technology is being examined as a means to measure adaptive variation for restoration ecology, as well as the effect of outbreeding on local gene pools. ${ }^{136}$ Whether there is sufficient regional genetic diversity in native species for breeding new traits needs to be determined. Ideally, ecological services provided by new ornamental cultivars of native species (e.g., native herbivore support) would be examined at a regional level.

\section{CONCLUSIONS}

It has been argued that the origin of a plant species has no bearing on whether it poses an ecological risk, ${ }^{38,138,139}$ although this is not a conclusion shared by many conservation biologists. ${ }^{149}$ Exotic plants have a complex effect on biodiversity in urban areas. ${ }^{140}$ Because new species are introduced into urban landscapes more rapidly than native species disappear, local biodiversity can remain high. ${ }^{141,142}$ The reduction of native shrub and tree cover, however, can alter the composition of native populations; ground-foraging bird species, for example, are favored over birds that are canopy foragers. ${ }^{41}$ Urbanization also tends to select for the same synanthropic species in different cities. ${ }^{142,143}$ Consequently, while diversity may remain high within a locality ( $\alpha$-diversity), the diversity between localities ( $\beta$-diversity) is reduced. ${ }^{2}$ The result of this trend is biotic homogenization. ${ }^{141,142}$ To maintain native biodiversity in urban landscapes, the cultivation of native plant species has been recommended. ${ }^{5,143-146}$

The extent to which native species need to be incorporated in esthetically managed landscapes to provide ecological services is not known. Small-scale additions of native ornamental plants in New York city community gardens did not increase beneficial insect richness. ${ }^{147}$ In contrast, landscaping with native shrubs and ground cover was found to increase the abundance and diversity of butterflies and birds in residential yards in Pennsylvania.' Suburbs of Canberra had significantly higher bird species richness when native trees made up more than $30 \%$ of the streetscape vegetation. ${ }^{4}$ This was assumed to be due to the increased foraging resources provided by native trees. To manage biodiversity in urban environments, residential landscapes should be considered as patches of interconnected habitat that can link other green spaces (e.g., parks, remnant forests). ${ }^{148} \mathrm{~A}$ proposal has been made to replace half the landscaping devoted to grass lawn in the United States with native plants, ${ }^{149}$ which would be equivalent to about $25 \%$ of the esthetically managed landscape.

To scale up native plants in landscaping to the $30 \%$ range will require that current constraints to their use be addressed.
Stakeholder surveys have found that the availability of native plants is a major limitation to increasing their use in landscaping. ${ }^{43,65-68}$ If native ornamentals were made more available through mainstream supply chains, it would likely be as a few selected genotypes of each species. This raises several interrelated questions, such as: what is the genetic diversity needed in a native plant species to provide ecological services regionally? What is the number of genotypes that can be provided profitably for regional markets? Is there sufficient genetic diversity within regionally appropriate germplasm for breeding ornamental traits?

Ecological objectives, including improved adaptation and sustainability, are receiving greater consideration in plant breeding. ${ }^{150}$ The development of native plants with ornamental traits could be accelerated using molecular breeding approaches, although the current market size of native landscaping plants may be insufficient to justify their cost. However, as ornamental shrubs and trees alone have an annual wholesale value of approximately $\$ 3$ billion in the United States, ${ }^{81}$ molecular breeding would be feasible if native species made up a larger part of that market. Tools from restoration ecology can be applied to address the genetic appropriateness of native plant material. Environmentally defined regions such as ecoregions or seed transfer zones may be useful as a platform for integrating economic, ecological and genetic research on native ornamental plants (Figure 1). An interdisciplinary approach could help resolve competing demands for ecological function, costeffective production and consumer appeal in native landscaping plants.

\section{COMPETING INTERESTS}

The authors declare no conflict of interest.

\section{ACKNOWLEDGEMENTS}

The authors thank Dr David Knauft and Dr Carol Robacker for helpful comments on the manuscript.

\section{REFERENCES}

1 Burghardt KT, Tallamy DW, Shriver WG. Impact of native plants on bird and butterfly biodiversity in suburban landscapes. Conserv Biol 2008; 23: 219-224.

2 Chong, KY, Teo S, Kurukulasuriya B, Chung YF, Rajathurai S, Tan HTW. Not all green is as good: different effects of the natural and cultivated components of urban vegetation on bird and butterfly diversity. Biol Conserv 2014; 171: 299-309.

3 Lerman SB, Warren PS. The conservation value of residential yards: linking birds and people. Ecol Appl 2011; 21: 1327-1339.

4 Ikin K, Knight E, Lindenmayer DB, Fischer J, Manning AD. The influence of native versus exotic streetscape vegetation on the spatial distribution of birds in suburbs and reserves. Divers Distrib 2013; 19: 294-306.

5 Paker Y, Yom-Tov Y, Alon-Mozes T, Barnea A. The effect of plant richness and urban garden structure on bird species richness, diversity and community structure. Landscape Urban Plan 2014; 122: 186-195.

6 Kramer MG. Our built and natural environments: a technical review of the interactions among land use, transportation, and environmental quality. Washington, DC: EPA, 2013. EPA report 231K13001, pp. 38-40.

7 Erlich PR, Raven PH. Butterflies and plants: a study in coevolution. Evolution 1964; 18: $586-608$.

8 Janz N. Ehrlich and Raven revisited: mechanisms underlying codiversification of plants and enemies. Annu Rev Ecol Evol Syst 2011; 42: 71-89.

9 Tallamy DW. Do alien plants reduce insect biomass? Conserv Biol 2004; 18: 1689692.

10 Burghardt KT, Tallamy DW, Philips C, Shropshire KJ. Non-native plants reduce abundance, richness, and host specialization in lepidopteran communities. Ecosphere 2010; 1: 1-22.

11 Burghardt KT, Tallamy DW. Plant origin asymmetrically impacts feeding guilds and life stages driving community structure of herbivorous arthropods. Divers Distrib 2013; 19: 1553-1565.

12 Martin LJ, Murray BR. A predictive framework and review of the ecological impacts of exotic plant invasions on reptiles and amphibians. Biol Rev 2011; 86: 407-419.

13 Mgobozi MP, Somers MJ, Dippenaar-Schoeman AS. Spider responses to alien plant invasion: the effect of short- and long-term Chromolaena odorata invasion and management. J Appl Ecol 2008; 45: 1189-1197. 
14 Hawkes CV, Belnap J, D'Antonio C, Firestone MK. Arbuscular mycorrhizal assemblages in native plant roots change in the presence of invasive exotic grasses. Plant Soil 2006; 281: 369-380.

15 Mummey DL, Matthias CR. The invasive plant species Centaurea maculosa alters arbuscular mycorrhizal fungal communities in the field. Plant Soil 2006; 288: 8190.

16 DeVore JL, Maerz JC. Grass invasion increases top-down pressure on an amphibian via structurally mediated effects on an intraguild predator. Ecology 2014; 95: 1724-1730.

17 Tallamy DW. Bringing Nature Home: How You Can Sustain Wildlife with Native Plants. Portland, OR: Timber Press, 2007.

18 Callicot JB, Lore GK. The nature of roadsides and the tools to work with it. Washington, DC: FHWA, 1999. Federal Highway Administration Publication FHWA-EP-03-005.

19 Alig RJ, Kline JD, Lichtenstein M. Urbanization on the US landscape: looking ahead in the 21st century. Landscape Urban Plan 2004; 69: 219-234.

20 USDA National Agricultural Statistics Service. Washington, DC: USDA ERS, 2014.

21 Nickerson C, Ebel R, Borchers A, Carriazo F. Major uses of land in the United States, 2007. Washington, DC: USDA ERS, 2011. USDA Economic Research Service EIB-89.

22 McKay JK, Christian CE, Harrison S, Rice KJ. How local is local?-a review of practical and conceptual issues in the genetics of restoration. Restor Ecol 2005; 13: 432-440.

23 Ballard M, Hough-Goldstein J, Tallamy D. Arthropod communities on native and nonnative early successional plants. Environ Entomol 2013; 42: 851-859.

24 Perre P, Loyola RD, Lewinsohn TM. Insects in urban plants: contrasting the flower head feeding assemblages on native and exotic hosts. Urban Ecosys 2011; 14: 711-722.

25 Cook-Patton, SC, Agrawal, AA. Exotic plants contribute positively to biodiversity functions but reduce native seed production and arthropod richness. Ecology 2014; 95: 1642-1650.

26 Heleno RH, Ceia RS, Ramos JA, Memmott J. Effects of alien plants on insect abundance and biomass: a food-web approach. Conserv Biol 2008; 23: 410-419.

27 Hengstum T, Hooftman DA, Oostermeijer JGB, Tienderen PH. Impact of plant invasions on local arthropod communities: a meta-analysis. J Ecol 2014; 102: 4-11.

28 Bezemer TM, Harvey JA, Cronin JT. Response of native insect communities to invasive plants. Annu Rev Entomol 2014; 59: 119-141.

29 Reichard SH, White P. Horticulture as a pathway of invasive plant introductions in the United States. BioScience 2001; 51: 103-113.

30 Loomis JD, Cameron GN. Impact of the invasive shrub Amur honeysuckle (Lonicera maackii) on shrub-layer insects in a deciduous forest in the eastern United States. Biol Invasions 2014; 16: 89-100.

31 Stireman JO, Devlin H, Doyle AL. Habitat fragmentation, tree diversity, and plant invasion interact to structure forest caterpillar communities. Oecologia 2014; 176 207-224.

32 Keeler MS, Chew FS. Escaping an evolutionary trap: preference and performance of a native insect on an exotic invasive host. Oecologia 2008; 156: 559-568.

33 Forister ML, Scholl CF. Use of an exotic host plant affects mate choice in an insect herbivore. Am Nat 2012; 179: 805-810.

34 Dietzsch AC, Stanley DA, Stout JC. Relative abundance of an invasive alien plant affects native pollination processes. Oecologia 2011; 167: 469-479.

35 Cappiccino N, Carpenter D. Invasive exotic plants suffer less herbivory than noninvasive exotic plants. Biol Lett 2005; 1: 435-438.

36 Lieurance D, Cipollini D. Exotic Lonicera species both escape and resist specialist and generalist herbivores in the introduced range in North America. Biol Invas 2013; 15: 1713-1724.

37 Sands DPA. Conserving the Richmond birdwing butterfly over two decades: where to next? Ecol Manage Restor 2008; 9: 4-16.

38 Davis, M. Do native birds care whether their berries are native or exotic? No. BioScience 2011; 61: 501-502.

39 Nagy, LR, Holmes RT. Food limits annual fecundity of a migratory songbird: an experimental study. Ecology 2005; 86: 675-681.

40 Granbom M, Smith, HG. Food limitation during breeding in a heterogeneous landscape. The Auk 2006; 123: 97-107.

41 Chace JF, Walsh JJ. Urban effects on native avifauna: a review. Landscape Urban Plan 2006; 74, 46-69.

42 Blair, RB. Birds and butterflies along an urban gradient: surrogate taxa for assessing biodiversity? Ecol Appl 1999; 9: 164-170.

43 Brzuszek RF, Harkess RL. Green industry survey of native plant marketing in the southeastern United States. HortTechnology 2009; 19: 168-172.

44 Armitage AM. Armitage's Native Plants for North American Gardens. Portland, OR: Timber Press, 2006.

45 Skelley K. Potentilla fruticosa 'KM01'. US Plant Patent application 20140026268, 2014.
46 Anonymous. A double-flowered redbud (Cercis candanesis var. plena). Missouri Bot Garden Bull 1935; 23: 77-78.

47 Flemer W. Hydrangea quercifolia. US Plant Patent 4458, 1979.

48 Oudshoorn HG. Monarda plant named 'Sugar Lace'. US Plant Patent 22918, 2012.

49 JR. Baptisia plant named 'Starlite'. US Plant Patent 19971, 2009.

50 Ault J. Breeding and development of new ornamental plants from North American native taxa. Acta Hort 2003; 624: 37-42.

51 Brand M. Aronia: native shrubs with untapped potential. Arnoldia 2010; 67: 14-25.

52 Werner DJ, Snelling LK. Cercis plant named 'Ruby Falls'. US Plant Patent 22097, 2011.

53 Windham MT, Trigiano RN, Witte WT. Dogwood tree named 'Kay's Appalachian Mist'. US Plant Patent 13098, 2002.

54 Lindgren DT, Schaaf DM. Penstemon: a summary of interspecific crosses. HortScience 2007; 42: 494-498.

55 NeSmith DS, Ehlenfeldt MK. 'Summer Sunset ${ }^{\mathrm{TM}}$ : a new ornamental blueberry. HortScience 2011; 46: 1560-1561.

56 Tenczar EG, Krischik VA. Effects of new cultivars of ninebark on feeding and ovipositional behavior of the specialist ninebark beetle, Calligrapha spiraeae (Coleoptera: Chrysomelidae). HortScience 2007; 42: 1396-1399.

57 Native plant partnership: UD, Mt. Cuba Center research how native plants contribute to healthy ecosystems. Newark, DE: University of Delaware; 7 July 2014. Available at http://www.udel.edu/udaily/2015/jul/healthyecosystems070714. html (accessed 12 November 2014).

58 Greenstone $\mathrm{MH}$, Olsen $\mathrm{RT}$, Buffington $\mathrm{ML}$ et al. Insect natural enemies in ornamental urban landscapes: parasitic hymenoptera in native and exotic residential-scale plots. In: Proceedings of the 24th USDA Interagency Research Forum on Invasive Species; 8-11 January; Annapolis, MD, USA. USDA: Washington, DC, USA, 2013, p. 32.

59 Omernik JM. Ecoregions of the conterminous United States. Ann Assoc Am Geog 1987; 77: 118-125.

60 Bower A, Clair BS, Erickson V. Generalized provisional seed zones for native plants. Ecol Appl 2010; 24: 913-919.

61 Vogel KP, Schmer MR, Mitchell RB. Plant adaptation regions: ecological and climatic classification of plant materials. Rangeland Ecol Manage 2005; 58: 315319.

62 Miller SA, Bartow A, Gisler M, Ward K, Young AS, Kaye TN. Can an ecoregion serve as a seed transfer zone? Evidence from a common garden study with five native species. Restor Ecol 2010; 19: 268-276.

63 Johnson GR, Sorensen FC, St Clair JB, Cronn RC. Pacific Northwest forest tree seed zones: a template for native plants? Native Plants J 2004; 5: 131-140.

64 Hall CR, Hodges AW, Palma MA. Sales, trade flows and marketing practices within the US nursery industry. J Environ Hort 2011; 29: 14-24.

65 Kauth PJ, Perez HE. Industry survey of the native wildflower market in Florida. HortTechnology 2011; 21: 779-788.

66 Hooper VH, Endter-Wada J, Johnson CW. Theory and practice related to native plants. Landscape J 2008; 27: 127-141.

67 Brzuszek RF, Harkess RL, Mulley S. Landscape architects' use of native plants in the southeastern United States. HortTechnology 2007: 17: 78-81.

68 Brzuszek RF, Harkess RL, Kelly L. Survey of Master Gardener use of native plants in the southeastern United States. HortTechnology 2010; 20: 462-466.

69 Heywood V. Conservation and sustainable use of wild species as sources of new ornamentals. Acta Hort 2001; 598: 43-53.

70 Cooper, CB, Dickinson J, Phillips T, Bonney R. Citizen science as a tool for conservation in residential ecosystems. Ecol Soc 2007; 12: 11.

71 van Heezik, YM, Dickinson KJM, Freeman C. Closing the gap: communicating to change gardening practices in support of native biodiversity in urban private gardens. Ecol Soc 2012; 17: 34.

72 Hinson RA, Paudel KP, Velastegui M, Marchant MA, Bosch DJ. Understanding ornamental plant market shares to rewholesaler, retailer, and landscaper channels. J Agr Appl Econ 2012; 44: 173-189.

73 Norcini J. Native plants: an overview. Tampa, FL: Florida Coop. Ext. Serv., Inst. Food Agr. Sci., Univ. Florida, 2006. ENH1045.

74 Helfand GE, Sik Park J, Nassauer Jl, Kosek S. The economics of native plants in residential landscape designs. Landscape Urban Plan 2006 78: 229-240.

75 Yue C, Hurley TM, Anderson N. Do native and invasive labels affect consumer willingness to pay for plants? Evidence from experimental auctions. Agric Econ 2011; 42: 195-205.

76 Yue C, Hurley T, Anderson NO. Heterogeneous consumer preferences for native and invasive plants: evidence from experimental auctions. HortScience 2012; 47: 1091-1095.

77 Stanton KM, Mickelbart MV. Maintenance of water uptake and reduced water loss contribute to water stress tolerance of Spiraea alba Du Roi and Spiraea tomentosa L. Hort Res 2014; 1: 14033. 
78 Arús P. Molecular markers for ornamental breeding. Acta Hort 2000; 508: 91-98.

79 Debener T, Byrne DH. Disease resistance breeding in rose: current status and potential of biotechnological tools. Plant Sci 2014; 228: 107-117.

80 Zhang F, Chen S, Chen F et al. Genetic analysis and associated SRAP markers for flowering traits of chrysanthemum (Chrysanthemum morifolium). Euphytica 2011; 177: 15-24.

81 Dobres MS. Barriers to genetically engineered ornamentals: an industry perspective. In: Floriculture, Ornamental and Plant Biotechnology. East Sussex: Global Science Books, 2008: 1-14.

82 Tallamy DW, Shropshire KJ. Ranking lepidopteran use of native versus introduced plants. Conserv Biol 2009; 23: 941-947.

83 Smith NR, Trigiano RN, Windham MT et al. AFLP markers identify Cornus florida cultivars and lines. J Am Soc Hort Sci 2007; 132: 90-96.

84 Wadl PA, Wang X, Trigiano AN et al. Molecular identification keys for cultivars and lines of Cornus florida and C. kousa based on simple sequence repeat loci. J Am Soc Hortic Sci 2008; 133: 783-793.

85 Hadziabdic D, Fitzpatrick BM, Wang X et al. Analysis of genetic diversity in flowering dogwood natural stands using microsatellites: the effects of dogwood anthracnose. Genetica 2010; 138: 1047-1057.

86 Wang X, Wadl PA, Rinehart TA et al. A linkage map for flowering dogwood (Cornus florida L.) based on microsatellite markers. Euphytica 2009; 165: 165-175.

87 Wadl PA, Saxton AM, Wang $X$ et al. Quantitative trait loci associated with red foliage in Cornus florida L. Mol Breeding 2011; 27: 409-416.

88 Rinehart TA, Robert NT, Phillip AW et al. Characterization of twelve microsatellite markers for the native redbud tree (Cercis canadensis). Mol Ecol Resources 2010; 10 : 751-754.

89 Wadl PA, Trigiano RN, Werner DJ, Pooler MR, Rinehart TA. Simple sequence repeat markers from Cercis canadensis show wide cross-species transfer and use in genetic studies. J Am Soc Hort Sci 2012; 137: 189-201.

90 Chappell M, Robacker C, Jenkins TM. Genetic diversity of seven deciduous azalea species (Rhododendron spp. section Pentanthera) native to the eastern United States. J Am Soc Hortic Sci 2008; 133: 374-382.

91 Wang H, Walla JA, Magnusson VA, Zhong S, Dai W. Construction of genetic linkage maps and QTL mapping for X-disease resistance in tetraploid chokecherry (Prunus virginiana L.) using SSR and AFLP markers. Mol Breeding 2014; 34: 143-157.

92 Dirlewanger E, Graziano E, Joobeur T et al. Comparative mapping and markerassisted selection in Rosaceae fruit crops. Proc Natl Acad Sci USA 2004; 101: 9891 9896.

93 Jung S, Ficklin SP, Lee T et al. The Genome Database for Rosaceae (GDR): year 10 update. Nucleic Acids Res 2014; 42: D1237-D1244.

94 Czarnecki DM, Rao MN, Norcini JG, Gmitter FG, Deng Z. Genetic diversity and differentiation among natural, production, and introduced populations of the narrowly endemic species Coreopsis leavenworthii (Asteraceae). J Am Soc Hort Sci 2008; 133: 234-241.

95 Tang S, Knapp SJ. Microsatellites uncover extraordinary diversity in native American land races and wild populations of cultivated sunflower. Theor Appl Genet 2003; 106: 990-1003.

96 Pashley $\mathrm{CH}$, Ellis JR, McCauley DE, Burke JM. EST databases as a source for molecular markers: lessons from Helianthus. J Heredity 2006; 97: 381-388.

97 Vanholme B, Cesarino I, Goeminne G et al. Breeding with rare defective alleles (BRDA): a natural Populus nigra HCT mutant with modified lignin as a case study. New Phytol 2013; 198: 765-776.

98 van Nocker S, Gardiner SE. Breeding better cultivars, faster: applications of new technologies for the rapid deployment of superior horticultural tree crops. Hort Res 2014; 1: 14022.

99 Till BJ. Mining genetic resources via ecotilling. In: Tuberosa R, Graner A, Frison E (ed.) Genomics of Plant Genetic Resources. Dordrecht: Springer, 2014: 349-365.

100 Ibiza VP, Canizares J, Nuez F. EcoTILLING in Capsicum species: searching for new virus resistances. BMC Genomics 2010; 11: 631

101 Wang NA, Shi L, Tian F et al. Assessment of FAE1 polymorphisms in three Brassica species using EcoTILLING and their association with differences in seed erucic acid contents. BMC Plant Biol 2010; 10: 137.

102 Olsen KM, Wendel JF. A bountiful harvest: genomic insights into crop domestication phenotypes. Annu Rev Plant Biol 2013; 64: 47-70.

103 Iwata H, Gaston A, Remay A et al. The TFL1 homologue KSN is a regulator of continuous flowering in rose and strawberry. Plant $J$ 2012; 69: 116-125.

104 Pnueli L, Carmel-Goren L, Hareven D et al. The SELF-PRUNING gene of tomato regulates vegetative to reproductive switching of sympodial meristems and is the ortholog of CEN and TFL1. Development 1998; 125: 1979-1989.

105 Tian Z, Wang X, Lee R et al. Artificial selection for determinate growth habit in soybean. Proc Natl Acad Sci USA 2010; 107: 8563-8568.

106 Liu Z, Zhang D, Liu D, Li F, Lu H. Exon skipping of AGAMOUS homolog PrseAG in developing double flowers of Prunus lannesiana (Rosaceae). Plant Cell Rep 2013; 32: $227-237$
107 Nitasaka E. Insertion of an En/Spm-related transposable element into a floral homeotic gene DUPLICATED causes a double flower phenotype in the Japanese morning glory. Plant J 2003; 36: 522-531.

108 Galimba KD, Tolkin TR, Sullivan AM, Melzer R, Theißen G, Di Stilio VS. Loss of deeply conserved C-class floral homeotic gene function and $\mathrm{C}$-and E-class protein interaction in a double-flowered ranunculid mutant. Proc Natl Acad Sci USA 2012; 109: 2267-2275.

109 Ashikari M, Sasaki A, Ueguchi-Tanaka M et al. Loss-of-function of a rice gibberellin biosynthetic gene, GA20 oxidase (GA20ox-2), led to the rice 'green revolution'. Breeding Sci 2002; 52: 143-150.

110 Bulley SM, Wilson FM, Hedden P, Phillips AL, Croker SJ, James DJ. Modification of gibberellin biosynthesis in the grafted apple scion allows control of tree height independent of the rootstock. Plant Biotechnol J 2005; 3: 215-223.

111 Xiao J, Li H, Zhang J et al. Dissection of GA 20-oxidase members affecting tomato morphology by RNAi-mediated silencing. Plant Growth Regul 2006; 50: 179-189.

112 Elias AA, Busov VB, Kosola KR et al. Green revolution trees: semidwarfism transgenes modify gibberellins, promote root growth, enhance morphological diversity, and reduce competitiveness in hybrid poplar. Plant Phys 2012; 160: 1130-1144.

113 Studer A, Zhao Q, Ross-Ibarra J, Doebley J. Identification of a functional transposon insertion in the maize domestication gene tb1. Nat Genet 2011; 43: 1160-1163.

114 Aguilar-Martínez JA, Poza-Carrión C, Cubas P. Arabidopsis BRANCHED1 acts as an integrator of branching signals within axillary buds. Plant Cell 2007; 19: 458-472.

115 Martín-Trillo M, Grandío EG, Serra F et al. Role of tomato BRANCHED1-like genes in the control of shoot branching. Plant J 2011; 67: 701-714.

116 Shulaev V, Korban SS, Sosinski B et al. Multiple models for Rosaceae genomics. Plant physiology 2008; 147: 985-1003.

117 IAEA Mutant Variety Database. Peach variety 'Plodiv 6'. Available at http:// mvgs.iaea.org/Search.aspx?ID=247 (accessed 18 December 2014).

118 Pooler MR, Scorza R. Irradiation and heat affect peach pollen germination and fertility. HortScience 1997; 32: 290-291.

119 Martin T, Hu M, Labbe H, McHugh S, Svircev A, Miki B. PpAG1, a homolog of AGAMOUS, expressed in developing peach flowers and fruit. Can J Bot 2006; 84: 767-776.

120 An L, Li T. Cloning, expression, and production of polyclonal antibodies of peach PpLFY. Acta Hort Sin 2008; 35: 1573-1580.

121 Zhang L, Xu Y, Ma R. Molecular cloning, identification, and chromosomal localization of two MADS box genes in peach (Prunus persica). J Genet Genomics 2008; 35: 365-372.

122 Tadiello, A, Pavanello A, Zanin D et al. A PLENA-like gene of peach is involved in carpel formation and subsequent transformation into a fleshy fruit. $J$ Expt Bot 2009; 60: 651-661.

123 Tani E, Polidoros AN, Flemetakis E et al. Characterization and expression analysis of AGAMOUS-like, SEEDSTICK-like, and SEPALLATA-like MADS-box genes in peach (Prunus persica) fruit. Plant Physiol Biochem 2009; 47: 690-700.

124 Yamane H, Ooka T, Jotatsu H, Sasaki R, Tao R. Expression analysis of PpDAM5 and PpDAM6 during flower bud development in peach (Prunus persica). Sci Hort 2011; 129: 844-848.

125 Chen $\mathrm{Y}$, Jiang $\mathrm{P}$, Thammannagowda S, Liang H, Wilde HD. Characterization of peach TFL1 and comparison with FT/TFL1 gene families of the Rosaceae. J Am Soc Hort Sci 2013; 138: 12-17.

126 Connors $\mathrm{CH}$. Some notes on the inheritance of unit characters in the peach. Proc Am Soc Hort Sci 1920; 16: 24-36.

127 Bailey JS, French, AP. The inheritance of blossom type and blossom size in the peach. Proc Am Soc Hort Sci 1942: 40: 248-250.

128 Pozzi C, Vecchietti A. Peach structural genomics. In: Folta KM, Gardiner SE, (ed.) Genetics and Genomics of Rosaceae. New York: Springer, 2009: 235-257.

129 Van Tuyl JM, Lim,K-B. Interspecific hybridisation and polyploidisation as tools in ornamental plant breeding. Acta Hort 2003: 612: 13-22.

130 Ranney TG, Frantz PR. $\times$ Gordlinia grandiflora (Theaceae): An intergeneric hybrid between Franklinia alatamaha and Gordonia lasianthus. HortScience 2006; 41: 1386-1388.

131 Jones JR, Ranney TG, Eaker TA. A novel method for inducing polyploidy in Rhododendron seedlings. J Am Rhododendron Soc 2008; 62: 130-135.

132 Zhang Z, Dai H, Xiao M, Liu X. In vitro induction of tetraploids in Phlox subulata L. Euphytica 2008; 159: 59-65.

133 Jones TA. When local isn't best. Evol Appl 2013; 6: 1109-1118.

134 Potter KM, Hargrove WW. Determining suitable locations for seed transfer under climate change: a global quantitative method. New Forests 2012; 43: 581-599.

135 Moncada KM, Ehlke NJ, Muehlbauer GJ et al. Genetic variation in three native plant species across the state of Minnesota. Crop Sci 2007; 47: 2379-2389.

136 Krauss SL, Sinclair EA, Bussell JD, Hobbs, RJ. An ecological genetic delineation of local seed source provenance for ecological restoration. Ecol Evol 2013; 3: 21382149. 
137 Williams AV, Nevill PG, Krauss SL. Next generation restoration genetics: applications and opportunities. Trends Plant Sci 2014; 19: 529-537.

138 Kendle AD, Rose JE. The aliens have landed! What are the justifications for 'native only' policies in landscape plantings? Landscape Urban Plan 2000; 47: 19-31.

139 Davis MA, Chew MK, Hobbs RJ et al. Don't judge species on their origins. Nature 2011; 474: 153-154.

140 Simberloff D. Non-natives: 141 scientists object. Nature 2011; 475: 36.

141 Qian H, Ricklefs RE. The role of exotic species in homogenizing the North American flora. Ecol Lett 2006; 9: 1293-1298.

142 McKinney ML. Urbanization as a major cause of biotic homogenization. Biol Conserv 2006; 127: 247-260.

143 Shochat E, Lerman SB, Anderies JM, Warren PS, Faeth SH, Nilon CH. Invasion, competition, and biodiversity loss in urban ecosystems. BioScience 2010; 60: 199-208.

144 McKinney ML. Urbanization, biodiversity, and conservation. BioScience 2002; 52: 883-890.

145 Lerman SB, Warren PS, Gan H, Shochat E. Linking foraging decisions to residential yard bird composition. PloS One 2012; 7: e43497.
146 Ellis EC, Antill EC, Kreft H. All is not loss: plant biodiversity in the Anthropocene. PloS One 2012; 7: e30535.

147 Matteson KC, Langellotto GA. Small scale additions of native plants fail to increase beneficial insect richness in urban gardens. Insect Conserv Divers 2011; 4: 89-98.

148 Goddard MA, Dougill AJ, Benton TG. Scaling up from gardens: biodiversity conservation in urban environments. Trends Ecol Evol 2010; 25: 90-98.

149 Tallamy DW. Available at http://ir.nrec.org/content/outside-presentation-drdoug-tallamy-author-bringing-home-nature (accessed 12 November 2014).

150 Brummer EC, Barber WT, Collier SM et al. Plant breeding for harmony between agriculture and the environment. Front Ecol Environ 2011; 9: 561-568.

(c) (i) $\Theta$ This work is licensed under a Creative Commons Attribution-

(c) ${ }_{\mathrm{BY}} \mathrm{NC}$ ND NonCommercial-NoDerivs 3.0 Unported License. The images or other third party material in this article are included in the article's Creative Commons license, unless indicated otherwise in the credit line; if the material is not included under the Creative Commons license, users will need to obtain permission from the license holder to reproduce the material. To view a copy of this license, visit http:// creativecommons.org/licenses/by-nc-nd/3.0/ 